\title{
Effects of thyroid hormone imbalance on colorectal cancer carcinogenesis and risk - a systematic review
}

\author{
Olga Rostkowska ${ }^{1}$, Piotr Spychalski ${ }^{1}$, Małgorzata Dobrzycka ${ }^{1}$, Maciej Wilczyński ${ }^{1}$, Andrzej J. Łachiński ${ }^{1}$, \\ Łukasz Obołończyk², Krzysztof Sworczak2, Jarek Kobiela ${ }^{1}$
}

${ }^{1}$ Department of General, Endocrine, and Transplant Surgery, Medical University of Gdansk, Poland

${ }^{2}$ Department of Endocrinology and Internal Medicine, Medical University of Gdansk, Poland

\begin{abstract}
Colorectal cancer (CRC) is the second leading cause of cancer-related death. The prevalence of colorectal neoplasm is increasing. Many studies have shown that thyroid dysfunction may be connected with the higher risk of pancreatic and breast cancer, but only a few described the role of thyroid dysfunction and thyroid hormone $(\mathrm{TH})$ replacement in the development and risk of CRC. The aim of this study is to summarise all findings and potentially elucidate the connection between TH imbalance and colorectal cancer.

The systematic review was conducted according to PICO and PRISMA guidelines. We searched MEDLINE, ClinicalTrials.gov, www.clinicaltrialsregister.eu, and Cochrane Library databases using the following keywords: "(((thyroid OR hypothyroidism OR hyperthyroidism OR levothyroxine OR hashimoto OR graves OR thyroidectomy)) AND (colon OR colorectal OR CRC)) NOT hashimoto[Author]) NOT graves[Author])". No filters were used.

Of total of 3054 articles identified by the search strategy, 11 met PICO criteria and were included into the review. Four of those were on cell lines and seven were human studies. Analysis of the included studies revealed an elevated risk of CRC in patients with hypothyroidism with aORs ranging from 1.16 (95\% CI: 1.08-1.24, $\mathrm{p}<0.001$ ) to 1.69 (95\% CI: 1.21-2.36, $\mathrm{p}=0.002)$. Moreover, TH replacement therapy has a protective effect for CRC risk with aOR ranging from 0.60 (95\% CI: $0.44-0.81, p=0.001)$ to 0.92 (95\% CI: $0.86-0.98, p=0.009)$. THs seem to play a role in colorectal carcinogenesis. Further studies are warranted to define the exact role of thyroid hormone imbalance in prevention and treatment of CRC. (Endokrynol Pol 2019; 70 (2): 190-197)
\end{abstract}

Key words: colorectal cancer; cancer risk; hypothyroidism; thyroid hormones; levothyroxine

\section{Introduction}

According to the American Cancer Society colorectal cancer (CRC) is the third most common cancer diagnosed in both men and women (excluding skin cancers) and the third leading cause of cancer-related deaths worldwide [1]. Although the treatment of CRC has improved over the last few decades, it is still expected to cause about $8 \%$ of cancer-related deaths in 2018 [1]. The five-year relative survival rates for people with stage I CRC is approximately $92 \%$ [2]. However, it decreases to $12 \%$ for patients in stage IV of the disease [2]. Therefore, it is still crucial to explore the nature of CRC development, progression, and risk factors.

The majority of CRCs develop from adenomatous polyps arising from the intestinal lining. This phenomenon is called adenoma-carcinoma sequence [3]. Numerous variables have been confirmed as risk factors of colorectal adenomas and CRC, such as obesity, physical inactivity, smoking, and low-fibre diet [4]. On the other hand, there are multiple agents showing a protective influence on risk of CRC. Widely used drugs like aspirin or metformin have already been found to have a preventive action against tumourigenesis of CRC $[5,6]$. However, data on TH imbalance and risk of CRC are still not comprehensively described.

Thyroxine, the main product of thyroid gland (T4), is an inactive form of TH. Type 1 (D1) and 2 deiodinases (D2) convert it into T3, which is its active form. Both $\mathrm{T} 3$ and $\mathrm{T} 4 \mathrm{can}$ be transformed into inactive metabolites via type 3 deiodinase (D3) [7]. Deregulation of the D3 function has been implicated in tumorigenesis of haemangiomas, hepatocellular carcinomas, and breast and thyroid cancer [8-10].

Multiple studies have shown a significant connection between hypothyroidism and pancreatic, gastric, and breast cancer [11, 12]. The association between the dysfunction of thyroid gland and CRC was not investigated as fully. Therefore, the aim of this study is to perform a systematic review on the association between THs imbalance and CRC risk and treatment.

Olga Rostkowska, Department of General, Endocrine, and Transplant Surgery, Medical University of Gdansk, Skłodowska 3A Str, 80-210 Gdansk, Poland, tel: (+48) 500081 056, e-mail: olga.r@gumed.edu.pl 


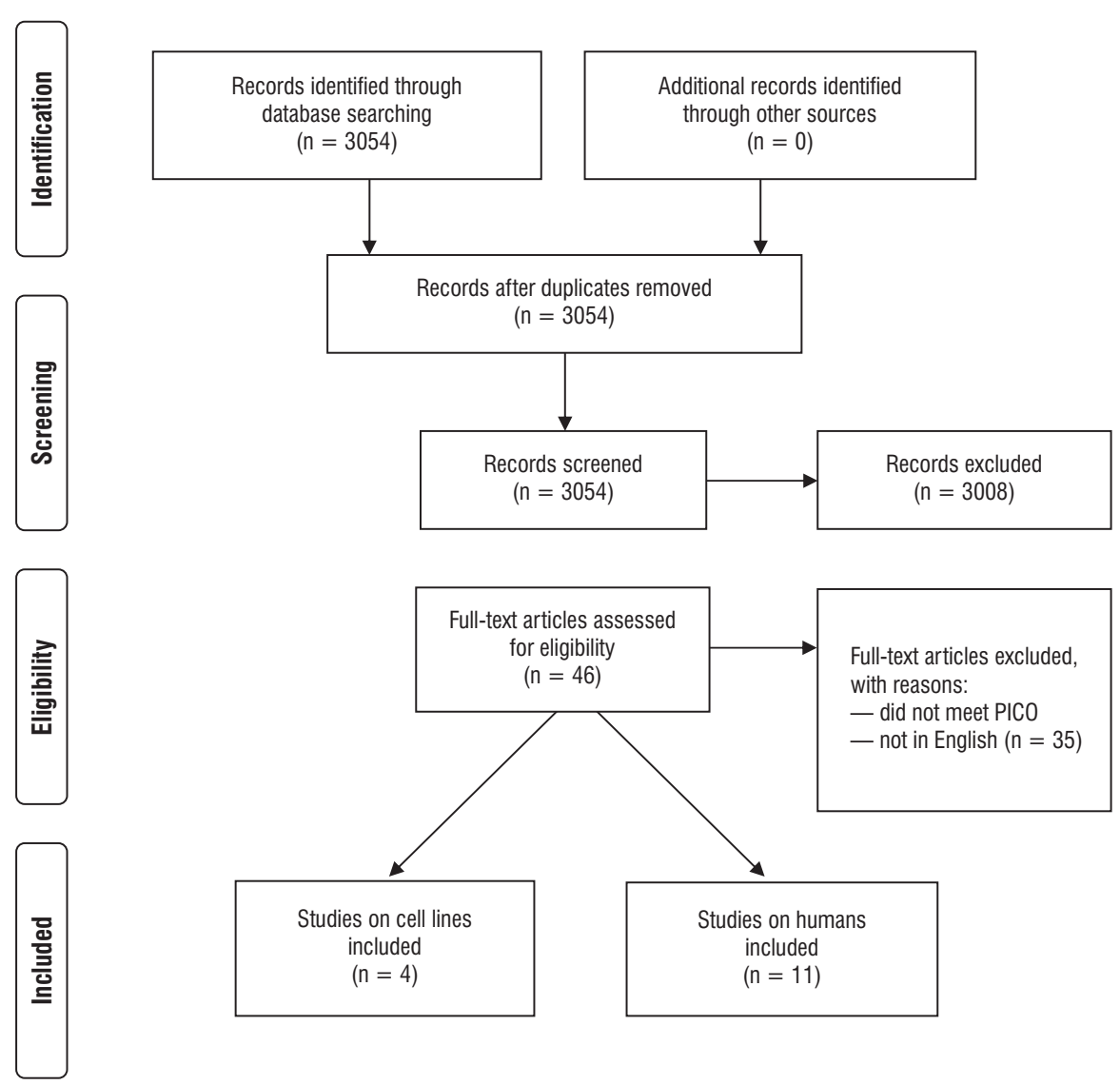

Figure 1. PRISMA protocol for data acquisition

\section{A systematic review}

\section{Search strategy and study acquisition}

This systematic review was performed according to PRISMA (Preferred Reporting Items for Systematic Reviews and Meta-Analyses) and PICO (Patients, Interventions, Comparisons, Outcomes) guidelines. On $7^{\text {th }}$ May 2018 the MEDLINE, ClinicalTrials.gov, www. clinicaltrialsregister.eu, and Cochrane Library databases were searched. The following search query was used: "(()(thyroid OR hypothyroidism OR hyperthyroidism OR levothyroxine OR hashimoto OR graves OR thyroidectomy)) AND (colon OR colorectal OR CRC)) NOT hashimoto[Author]) NOT graves[Author]". No filters were active. Two independent researchers screened results. The initial search returned 3054 results. After screening of abstracts, 46 results were chosen for full text analysis, of which 11 met inclusion criteria and were included in the study. A flowchart of study inclusion is presented in Figure 1.

\section{Inclusion and exclusion criteria}

Studies were included into analysis if predefined PICO criteria were met (Tab. I). Articles were dichotomised
Table I. PICO criteria used in the study

\begin{tabular}{ll}
\hline Part A & \\
\hline PIC0 & Description \\
\hline Patients & Cell studies: \\
& $\begin{array}{l}\text { Studies on colorectal cancer cell lines } \\
\text { And/or studies on colorectal cancer stem cells }\end{array}$ \\
\hline Intervention & Use of: T3, T4, or D3 inhibitors \\
\hline Comparisons & Cell lines exposed to change in thyroid hormone \\
& $\begin{array}{l}\text { levels were compared to cell lines not exposed to } \\
\text { such changes }\end{array}$ \\
\hline Outcomes & Rates of differentiation and proliferation \\
\hline Part B & Description \\
\hline PICO & $\begin{array}{l}\text { Patients with diagnosed colorectal cancer } \\
\text { Patients with diagnosed thyroid diseases } \\
\text { (subclinical hypothyroidism, hyperthyroidism) }\end{array}$ \\
\hline Intervention & - \\
\hline Comparisons & $\begin{array}{l}\text { Patients exposed to higher or lower levels } \\
\text { or thyroid hormones were compared } \\
\text { of thyroid hormones }\end{array}$ \\
\hline Colorectal cancer risk \\
\hline
\end{tabular}


Table II. Cell lines studies

\begin{tabular}{|c|c|c|c|c|c|}
\hline $\begin{array}{l}\text { First author } \\
\text { Year of the study }\end{array}$ & $\begin{array}{l}\text { Type of studied } \\
\text { cells }\end{array}$ & $\begin{array}{l}\text { The aim } \\
\text { of the study }\end{array}$ & Mechanism & Outcomes & Conclusions \\
\hline $\begin{array}{l}\text { Dentice M. et al. } \\
2012 \text { [21] }\end{array}$ & $\begin{array}{l}\text { Colon cancer cell } \\
\text { lines }\end{array}$ & $\begin{array}{l}\text { The role of } \mathrm{D} 3 \text { in } \\
\text { the regulation of } \mathrm{T} 3 \\
\text { signalling in cancer } \\
\text { cells }\end{array}$ & $\begin{array}{l}\text { Absence of D3 } \\
\text { increases level } \\
\text { of } \mathrm{T3}\end{array}$ & $\begin{array}{l}\text { Higher level of T3 inhibits } \\
\text { colon cancer cells } \\
\text { proliferation and promotes } \\
\text { differentiation in cultured } \\
\text { cells }\end{array}$ & $\begin{array}{l}\text { Regulation of T3 may } \\
\text { be targeted to reduce } \\
\text { the oncogenic effects of } \\
\beta \text {-catenin in intestinal cells }\end{array}$ \\
\hline $\begin{array}{l}\text { Catalano V. et al. } \\
2015 \text { [13] }\end{array}$ & $\begin{array}{l}\text { Colorectal cancer } \\
\text { stem cells }\end{array}$ & $\begin{array}{l}\text { Influence of D3 and } \\
\text { T3 on colorectal } \\
\text { cancer stem cells }\end{array}$ & $\begin{array}{l}\text { Depletion of } \\
\text { D3 increases } \\
\text { intracellular } \\
\text { thyroid hormone } \\
\text { concentration }\end{array}$ & $\begin{array}{l}\text { Higher level of T3 induces } \\
\text { cell differentiation and } \\
\text { sharply mitigate tumour } \\
\text { formation }\end{array}$ & $\begin{array}{l}\text { Combined action on } \\
\text { intracellular T3 and } \\
\text { chemotherapy could } \\
\text { improve colorectal cancer } \\
\text { treatment }\end{array}$ \\
\hline $\begin{array}{l}\text { Lee Y.-S. et al. } \\
2018 \text { [22] }\end{array}$ & $\begin{array}{l}\text { Colorectal cancer } \\
\text { cells }\end{array}$ & $\begin{array}{l}\text { Influence of T4 on } \\
\text { colorectal cancer } \\
\text { cells }\end{array}$ & $\begin{array}{l}\text { T4 induces } \\
\text { nuclear B-catenin } \\
\text { accumulation, as } \\
\text { well as high cyclin } \\
\text { D1 and c-Myc }\end{array}$ & $\begin{array}{l}\text { T4 promotes B-catenin } \\
\text { activation and cell- } \\
\text { proliferation in colorectal } \\
\text { cancer }\end{array}$ & $\begin{array}{l}\text { An applicable therapeutic } \\
\text { strategy including T4 } \\
\text { regulation could be } \\
\text { considered }\end{array}$ \\
\hline $\begin{array}{l}\text { Zhu L. et al. } \\
2016 \text { [17] }\end{array}$ & $\begin{array}{l}\text { Normal colon } \\
\text { mucosa cells, } \\
\text { human colorectal } \\
\text { cancer cells }\end{array}$ & $\begin{array}{l}\text { The role of TRB1 } \\
\text { in the CRC tissues } \\
\text { and cells }\end{array}$ & $\begin{array}{l}\text { TRB1 works via the } \\
\text { PI3K/Akt pathway }\end{array}$ & $\begin{array}{l}\text { TRB1 plays a critical role in } \\
\text { the progression of CRC }\end{array}$ & $\begin{array}{l}\text { TRB1 could be a potential } \\
\text { target for } C R C \text { therapeutics }\end{array}$ \\
\hline
\end{tabular}

CRC — colorectal cancer

into two categories: cell-line studies (Tab. I, part A) and human studies (Tab. I, part B).

\section{Evidence extraction and synthesis}

Information from studies that met eligibility criteria on cell lines was abstracted by two independent researchers into Table II. Information from studies that met eligibility criteria on humans was abstracted by two independent researchers into Table III.

\section{Results}

A total of 11 studies met predefined PICO criteria and were dichotomised into two categories: cell-line studies and human studies. No studies on animals were available.

\section{Cell lines studies}

A total of four studies were included into the review. Results are summarised in Table II. Included studies were based on varying methodology. One study was on CRC stem cells, and three studies were on CRC cells. Characteristics of included studies are summarised in Table II.

A study by Catalano et al. focused on the role of THs in CRC stem cell differentiation and their sensitivity to chemotherapy [13]. CRC stem cells (CR-CSC) are a small group of cells with self-renewing potential and the ability to induce tumour growth [14, 15]. CSCs are highly insensitive to chemotherapy and other kinds of treatment, which can lead to inefficient management of the disease [16]. One of the factors determining the potential survival of stem cells, the possibility of their self-renewal and resistance to chemotherapy, is the Wnt signalling pathway. It controls the sequence of events leading to the neoplastic transformation of colon mucosa. Catalano et al. proved that Wnt-b-catenin pathway drives an inverse, coordinated regulation of D2 and D3 in CRC cells. Moreover, they demonstrated that CR-CSCs are highly sensitive to intracellular T3, while D3 maintains CRC stem cells in the undifferentiated status and enhances tumour growth. T3 appears effective in inducing cell differentiation, affects the Wnt target-related genes, and makes the CR-CSCs more sensitive to chemotherapy. The results of the study suggest that the effect of chemotherapy on T3-induced cells could be superior to the effect chemotherapy on normal CRC cells.

Zhu et al. investigated the role of $\mathrm{TH}$ receptor $\beta 1$ (TR $\beta 1)$ in the progression of CRC [17]. Mutations of TRs have already been found to play a role in many kinds of cancers (such as breast, thyroid, hepatocellular, and renal clear cell cancer) $[9,10,18,19]$. Additionally, mice in which mutated TR gene have been introduced develop follicular thyroid cancer with enhanced capabilities of metastasising to the lungs [20]. Zhu et al. analysed 222 tissue samples from patients with CRC. Decreased expression of TR $\beta 1$ mRNA in colon and rectum adenocarcinoma samples was found in $89.7 \%$ of samples. Furthermore, the study analysed the correlation between $\operatorname{TR} \beta 1$ protein expression and clinicopathological characteristics of the CRC cases. It 


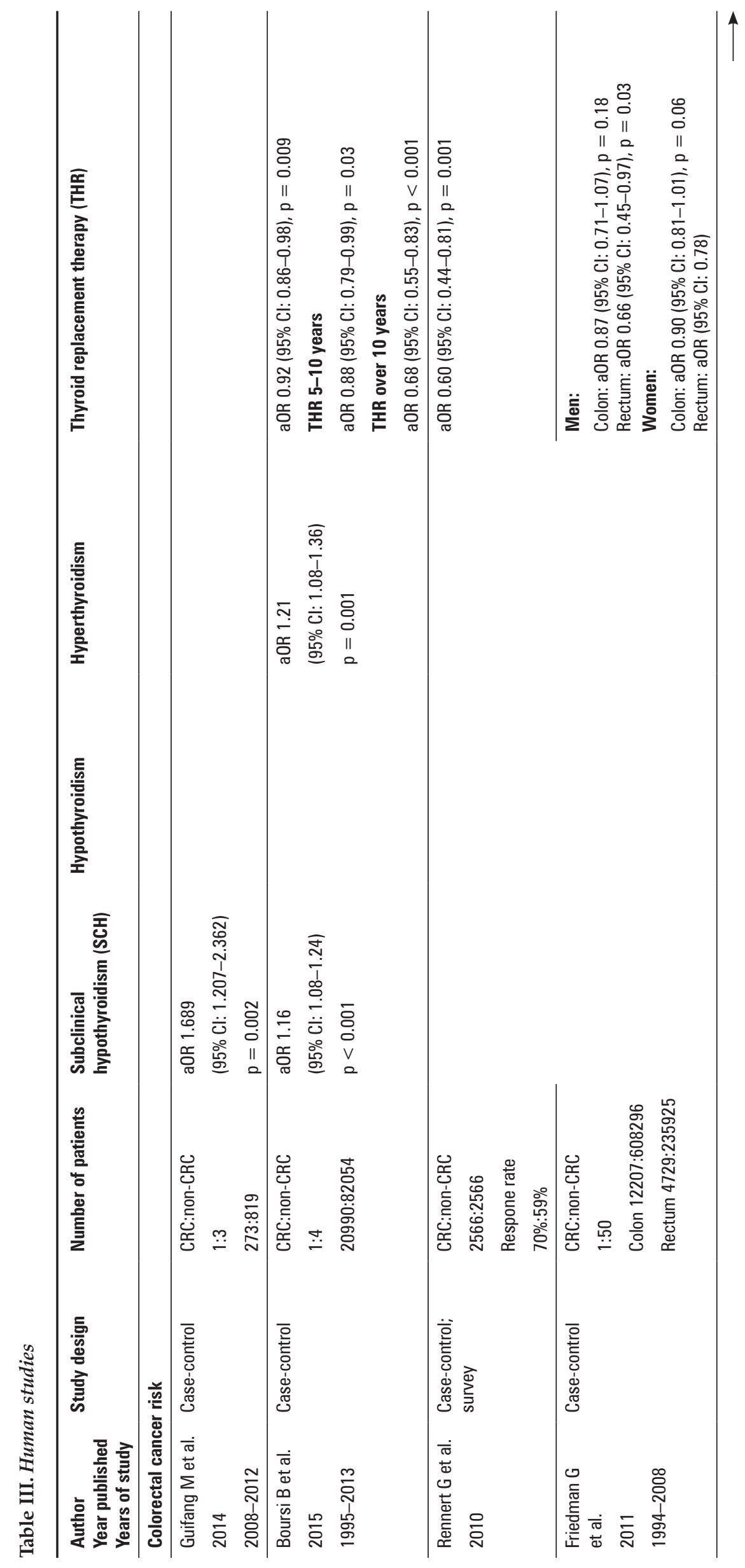




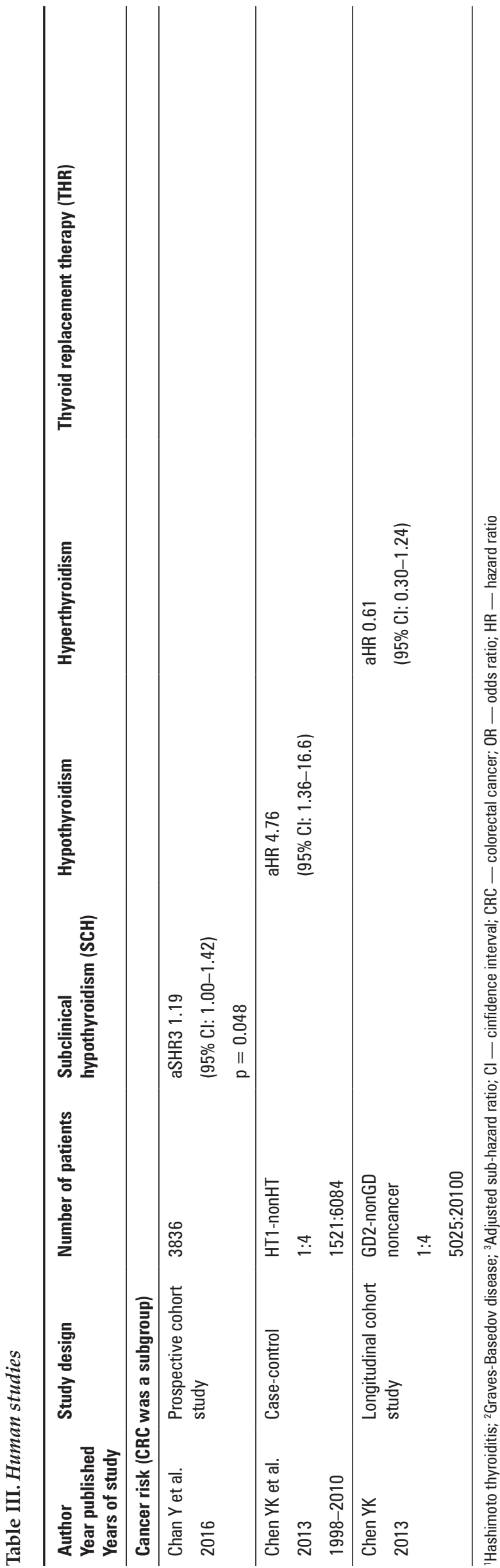

resulted in a statistically significant $(\mathrm{p}=0.045)$ inverse relation between the tumour size and TR $\beta 1$ expression, i.e. the expression was lower in tumours larger than 5 $\mathrm{cm}$. Moreover, the results showed that overexpression of TR $\beta 1$ inhibits CRC cell proliferation and suppresses the migration of the cells by inhibiting PI3K/Akt signalling. All the findings could suggest that TR $\beta 1$ plays an important role in CRC progression by regulating PI3K/AKT pathway and can be a future target in CRC therapy.

Another cell line study was conducted by Dentice et al. and investigated the role of D3 in the regulation of T3 signalling in cancer cells [21]. The study explored the correlation between D3 expression in CRC cells and B-catenin complex. The results showed that B-catenin up-regulation of D3 leads to reduced levels of T3, which inhibits differentiation and promotes cellular proliferation. A higher level of D3 was also found in adenomatous epithelium and CRC. The conclusion of the study was that affecting B-catenin-D3-T3 pathway could be a potential target for new CRC therapies.

Only Lee et al. presented results in contrast to those described above [22]. Their study investigated the role of T4 in CRC cell lines and its effect on B-catenin activation. According to the study, T4 enhanced cell proliferation in both CRC cell lines used (HCT 116 and HT-29) by hyper-activation of Wnt/B-catenin cascade. Higher level of B-catenin was connected with faster progression of the disease and unfavourable survival. However, Lee et al. pointed out that T4 and T3 may present different functions in the progression of CRC, and the relationships between THs require deeper exploration.

\section{Human studies}

A total of seven studies on humans were included into the analysis. Of those, four analysed only CRC risk and three analysed CRC as a subgroup. Five of the seven were case-control studies. The remaining two were cohort studies. Only one study was prospective. The characteristics of the included studies are summarised in Table III.

Rennert et al. in a case-control study on 2566 matched pairs showed that TH replacement therapy is associated with lower risk of CRC, with OR $=0.59(95 \%$ CI: $0.43-0.82, p=0.001$ ) [23]. After being adjusted for age, sex, use of aspirin and statins, sports activity, family history of CRC, ethnic group, and level of vegetable consumption, the results remained statistically significant with aOR $=0.60$ (95\% CI: 0.44-0.081, $\mathrm{p}=0.001$ ). In accordance with the well-known fact that hypothyroidism is much more common in women than in men, the study showed that levothyroxine supplementation was more frequent in female than in male control subjects $(8.2 \%$ vs. $2.0 \%$, respectively, $\mathrm{p}<0.0001)$. While reduction of CRC in men with 
levothyroxine supplementation was not statistically significant $(\mathrm{OR}=0.75,95 \% \mathrm{CI}: 0.42-1.36, \mathrm{p}=0.35)$, the association in women was $(\mathrm{OR}=0.54,95 \% \mathrm{CI}$ : $0.38-0.75, p<0.0001)$. After subgroup analysis, the study showed reduced risk of CRC in postmenopausal women supplementing levothyroxine $(\mathrm{OR}=0.53$, 95\% CI: $0.37-0.74, \mathrm{p}<0.001)$. Furthermore, analysis was adjusted for hormone (oestrogen) replacement therapy (HRT), and the results showed a statistically significant effect among non-HRT users $(\mathrm{OR}=0.49$, 95\% CI: $0.33-0.74, \mathrm{p}<0.001)$ but not among HRT users $\left(\mathrm{OR}=0.90,95 \% \mathrm{CI}: 0.35-2.36, \mathrm{P}_{\text {interaction }}=0.19\right)$. In the fully adjusted model for postmenopausal women, levothyroxine supplementation was related with significant reduction in $\mathrm{CRC}$ risk $(\mathrm{OR}=0.60,95 \% \mathrm{CI}$ : 0.4-0.81, $\mathrm{p}=0.001$ ).

As a response to the study by Rennert et al., Friedman et al. published data on 12,207 patients with colon cancer and 4729 with rectum/rectosigmoid cancer [24]. Each patient was matched with 50 controls. According to this study, rectal cancer risk was lower in men supplementing levothyroxine for at least five years $(\mathrm{OR}=0.66,95 \% \mathrm{CI}: 0.45-0.97, \mathrm{p}=0.03)$. Risk reduction of colon cancer was not statistically significant. The risks for postmenopausal women, both HRT users and non-users, were slightly reduced but not statistically significant.

Boursi et al. published data from a nested case-control study on a large UK population, showing similar results [25]. A total of 20,990 CRC patients were matched with 82,054 controls. The study focused on determining the risk of developing CRC as a result of thyroid dysfunction with TH replacement, as well as without it. Patients with $\mathrm{TH}$ replacement history were included into the study. Analysis of CRC risk was stratified by time of THs supplementation (0-6 months, 6-12 months, 1-5 years, 5-10 years, and > 10 years before index data) because the process of CRC tumorigenesis is multistep and lasts from 10 to 15 years. Adjusted OR for CRC in thyroxine-users was 0.88 (95\% CI: 0.79-0.99, p = 0.03) and 0.68 (95\% CI: $0.55-0.83, \mathrm{p}<0.001)$ for treatment initiated 5 to 10 years and more than 10 years before index data, respectively. The results were adjusted for age, male sex, diabetes mellitus, smoking, alcohol use, and NSAID use. The analysis of the association between timing of TH replacement initiation and CRC risk showed that the protective influence is increased with cumulative duration of therapy. Moreover, the patients with clinical or subclinical hypothyroidism with no history of THR had higher risk of CRC compared to patients without any thyroid dysfunction $(\mathrm{OR}=1.16,95 \% \mathrm{CI}$ : 1.08-1.24, p < 0.001). Hyperthyroidism was also associated with an increased $\mathrm{CRC}$ risk $(\mathrm{OR}=1.21,95 \% \mathrm{CI}$ : $1.08-1.36, \mathrm{p}=0.001)$.
A case-control study by Guifang et al. analysed 273 colorectal neoplasm patients matched with 819 controls [26]. The prevalence of subclinical hypothyroidism (SCH) was significantly higher in group of patients with colorectal neoplasm, compared to those without $(\mathrm{p}<0.01)$. Colorectal neoplasms were found in 67 (34.9\%) subjects in the SCH group, which was more than that in euthyroid group $(206,24.1 \%, \mathrm{p}=0.002)$. Moreover, patients with SCH were more likely to have advanced colonic lesions and CRC compared with euthyroid subjects ( $\mathrm{p}=0.028$ and $\mathrm{p}=0.036$, respectively). After adjusting for blood pressure, body mass index, history of hypertension, and smoking, an association still existed between colorectal neoplasm and $\mathrm{SCH}$ $(\mathrm{OR}=1.689,95 \% \mathrm{CI}: 1.21-2.36, \mathrm{p}=0.002)$. The authors concluded that a strong association between SCH and colorectal neoplasm was identified. SCH was found to be an independent risk factor for colorectal neoplasm.

Furthermore, three studies on cancer risk and TH imbalance contained data on CRC. A prospective cohort study by Chen et al. on 3863 patients reported adjusted hazard ratio (HR) of 1.19 (95\% CI: 1.00-1.42, $\mathrm{p}=0.048$ ) of CRC for patients with subclinical hypothyroidism (SCH) [27]. Chen et al. in 2013 published data from a case-control study on 1521 patients with Hashimoto disease (HD) matched with 6084 non-Hashimoto and reported adjusted HR of 4.76 of developing CRC (95\% CI: 1.36-16.6. $\mathrm{p}<0.05)$ [28]. The same authors reported data from a longitudinal cohort study on 5025 patients with Graves-Basedow disease (GD) matched with non-GD patients, which revealed a protective effect of this disease on CRC risk with aHR of 0.61 (95\% CI: $0.30-1.24, \mathrm{p}<0.001$ ) [29]

\section{Discussion}

The development of preventive strategies in CRC is a subject of extensive research. The relationship between CRC risk and some widely used medications such as metformin or statins has been described and showed promising results $[5,6,30]$. Another possible factor influencing the development of CRC is an imbalance of thyroid hormones resulting from diseases such as: subclinical hypothyroidism, Hashimoto's disease, and Graves-Basedow disease, and their treatment. The first report on the protective effects of THs replacement therapy on CRC risk was published by Rennert et al. in 2010 [23]. Further studies were in accordance with those results, showing that high concentrations (but within range) of THs diminishes the risk of CRC. Despite those promising initial results, to date only 11 papers analysing this subject are available, both on molecular and epidemiological level. Therefore, more thorough examination of this subject seems warranted. 


\section{Cell lines studies}

In vitro studies analysed in our review showed encouraging results; however, to date only four papers were published. Despite being based on varying methodologies, two of four came to similar conclusions, suggesting that higher concentrations of T3 achieved by inhibition of D3 serve as an inhibitor of tumourigenesis. Moreover, one study explored the role of TRb1 in cancer progression, which could become a target for molecular therapy. Only one study by Lee showed unfavourable results, i.e. that $\mathrm{T} 4$ promotes cancer proliferation. However, T4 is not a biologically active form, and therefore these results should be interpreted cautiously. All included cell-line studies bear limitations of a very specific design, which analyses only certain scenarios, such as inhibition of D3. It would be of great interest to compare the influence of $\mathrm{T} 3$ versus $\mathrm{T} 4$ on proliferation and differentiation of CRC cell lines and CRC CSC, to fully understand the role of TSH-T4-T3 axis on CRC development. Additional points of interest are the influence of TSH on peripheral cells as well as rT3, which contributes to $0.9 \%$ of THs in the bloodstream [31]. Furthermore, the presented studies analyse the influence of inhibition of only one enzyme: D3 deiodinase, while there are more enzymes that take part in metabolic pathways of $\mathrm{T} 4$ and $\mathrm{T} 3$, such as deiodinase type 1 and 2. Inhibition or activation of those enzymes could potentially influence the tumourigenesis of CRC and therefore could be a future target for molecular therapy. Some existing studies describe in detail the relationships and interdependences between THs and CRC, but straightforward conclusions on the effects of those relationships are lacking. Those conclusions (i.e. whether $\mathrm{T} 3$ or $\mathrm{T} 4$ promote or inhibit carcinogenesis) could be an essential foundation for potential animal and human studies. In summary, initial in vitro studies on the influence of THs on CRC show promising results. However, further research is needed - both to confirm available results and to explore other possible associations between the THs axis and CRC. This will enable clear conclusions to be drawn, which would be the rationale for animal and human studies.

\section{Animals studies}

The search strategy of this review identified no studies conducted on animals, despite the fact that similar scenarios were tested with metformin, aspirin, or statins [6, 32]. Animal studies investigating the effect of metformin showed that it reduces aberrant crypt foci formation and downregulates tumour angiogenesis. Aspirin has been shown to prevent colorectal cancer and CRC metastasis in mice. Such studies could contribute to the state of knowledge of association of levothyroxine supplementation and CRC risk.

\section{Human studies}

Studies on humans included in this analysis show consistent and promising results. Concentrations of THs within the upper limit of normal correlate with lower risk of CRC in all of the analysed studies. However, the quality of available data is moderate due to retrospective study designs, which are susceptible to multiple biases. Moreover, there are numerous factors contributing to cancer risk in general and CRC risk specifically, such as age, sex, diet, region of residence, or medications. On the other hand, epidemiology of thyroid diseases is also age- and sex-dependent. Therefore, it is essential to perform adjusted analyses of CRC risk that include both typical risk factors (such as age and sex) and less typical such as common medications that are known to influence CRC risk, including metformin and aspirin. The included studies report adjusted ORs; however, factors included into adjustment are varied. Moreover, there is a trend towards supplementation of $\mathrm{T} 4$ both in healthy individuals and in individuals with $\mathrm{SCH}$ [33]. Therefore, in light of growing use of TH supplements, it is essential to explore possible connections between level of supplementation and CRC risk. Furthermore, existing studies did not analyse dose escalation of T4 supplementation and did not report information on how the dose was established. This is of great interest because dose escalation of other drugs that serve a protective role in CRC risk enhanced this effect. Another interesting aspect of TH replacement is the time of exposure. Typically, patients who suffer from hypothyroidism are diagnosed in their twenties, while the average age of CRC diagnosis is $60+$ years old. Therefore, time of exposure is substantially longer in comparison to other drugs that may serve a protective role in $\mathrm{CRC}$, such as the aforementioned metformin or aspirin.

The main strength of this study is its novelty. This is, to our knowledge, the first available systematic review on the influence of $\mathrm{TH}$ imbalance on CRC. It systematically summarises findings on the topic in a Cochrane-style manner, which is another important quality.

The main limiting factor of the present study is the volume of included studies. This is due to scarce amounts of series available in the literature. This limits the possibilities to draw clear and definitive conclusions, a trend is visible nonetheless. Moreover, some of the studies acquired data via questionnaires in a retrospective manner and therefore are susceptible to recall bias. Most of the studies included into the review were case-control studies and therefore were susceptible to time window bias, i.e. a bias resulting from measuring exposure over unequal time intervals. 
In conclusion, based on our literature review, there is growing evidence suggesting a possible role of euthyreosis in CRC prevention and treatment. Further studies are required to validate these results.

\section{References}

1. Nowotwory złośliwe jelita grubego (C18-21). KRN. http://onkologia.org pl/nowotwory-zlosliwe-jelita-grubego-c18-21/. (July 10, 2018).

2. Society AC. Society AC. Survival Rates for Colorectal Cancer, by Stage.

3. Brenner H, Hoffmeister M, Stegmaier C, et al. Risk of progression of advanced adenomas to colorectal cancer by age and sex: estimates based on 840,149 screening colonoscopies. Gut. 2007; 56(11): 1585-1589, doi: 10.1136/gut.2007.122739, indexed in Pubmed: 17591622

4. Colussi D, Fabbri M, Zagari RM, et al. Lifestyle factors and risk for colorectal polyps and cancer at index colonoscopy in a FIT-positive screening population. United Eur Gastroenterol J. 2018; 6(6): 935-942, doi: 10.1177/2050640618764711, indexed in Pubmed: 30023072

5. Sehdev A, O'Neil BH, Sehdev A, et al. The Role of Aspirin, Vitamin D, Exercise, Diet, Statins, and Metformin in the Prevention and Treatment of Colorectal Cancer. Curr Treat Options Oncol. 2015; 16(9): 43, doi: 10.1007/s11864-015-0359-z, indexed in Pubmed: 26187794.

6. Kobiela J, Dobrzycka M, Jędrusik P, et al. Metformin and Colorectal Cancer - A Systematic Review. Exp Clin Endocrinol Diab. 2018, doi: 10.1055/a-0621-8830, indexed in Pubmed: 29954001.

7. Peeters RP, Visser TJ. Metabolism of Thyroid Hormone. MDText, South Dartmouth 2000

8. Giani C, Fierabracci P, Bonacci R, et al. Relationship between breast cancer and thyroid disease: relevance of autoimmune thyroid disorders in breast malignancy. J Clin Endocrinol Metab. 1996; 81(3): 990-994, doi: 10.1210/jcem.81.3.8772562, indexed in Pubmed: 8772562.

9. Silva JM, Domínguez G, González-Sancho JM, et al. Expression of thyroid hormone receptor/erbA genes is altered in human breast cancer Oncogene. 2002; 21(27): 4307-4316, doi: 10.1038/sj.onc.1205534, indexed in Pubmed: 12082618

10. Lin KH, Shieh HY, Chen SL, et al. Expression of mutant thyroid hormone nuclear receptors in human hepatocellular carcinoma cells. Mo Carcinog. 1999; 26(1): 53-61, indexed in Pubmed: 10487522.

11. Sarosiek K, Gandhi AV, Saxena S, et al. Hypothyroidism in Pancreatic Cancer: Role of Exogenous Thyroid Hormone in Tumor Invasion-Preliminary Observations. J Thyroid Res. 2016; 2016: 2454989 , doi: 10.1155/2016/2454989, indexed in Pubmed: 27123358

12. Brown AR, Simmen RCM, Simmen FA, et al. The role of thyroid hormone signaling in the prevention of digestive system cancers. Int J Mo Sci. 2013; 14(8): 16240-16257, doi: 10.3390/ijms140816240, indexed in Pubmed: 23924944.

13. Catalano V, Dentice M, Ambrosio R, et al. Activated Thyroid Hormone Promotes Differentiation and Chemotherapeutic Sensitization of Colorectal Cancer Stem Cells by Regulating Wnt and BMP4 Signaling. Cancer Res. 2016; 76(5): 1237-1244, doi: 10.1158/0008-5472.CAN-15-1542, indexed in Pubmed: 26676745.

14. Ricci-Vitiani L, Lombardi DG, Pilozzi E, et al. Identification and expansion of human colon-cancer-initiating cells. Nature. 2007; 445(7123): 111-115, doi: 10.1038/nature05384, indexed in Pubmed: 17122771.

15. Szaryńska M, Olejniczak A, Kobiela J, et al. Therapeutic strategies agains cancer stem cells in human colorectal cancer. Oncol Lett. 2017; 14(6): 7653-7668, doi: 10.3892/ol.2017.7261, indexed in Pubmed: 29250169.

16. Todaro M, Alea MP, Di Stefano AB, et al. Colon cancer stem cells dictate tumor growth and resist cell death by production of interleukin-4. Cell Stem Cell. 2007; 1(4): 389-402, doi: 10.1016/j.stem.2007.08.001, indexed in Pubmed: 18371377.
17. Zhu L, Tian G, Yang Q, et al. Thyroid hormone receptor 1 suppresses proliferation and migration by inhibiting PI3K/Akt signaling in human colorectal cancer cells. Oncol Rep. 2016; 36(3): 1419-1426, doi: 10.3892/or.2016.4931, indexed in Pubmed: 27431682

18. Puzianowska-Kuznicka M, Nauman A, Madej A, et al. Expression of thyroid hormone receptors is disturbed in human renal clear cell carcinoma. Cancer Lett. 2000; 155(2): 145-152, doi: 10.1016/S0304-3835(00)00416-X, indexed in Pubmed: 10822129.

19. Puzianowska-Kuznicka M, Krystyniak A, Madej A, et al. Functionally impaired TR mutants are present in thyroid papillary cancer. J Clin Endocrinol Metab. 2002; 87(3): 1120-1128, doi: 10.1210/jcem.87.3.8296, indexed in Pubmed: 11889175.

20. Suzuki H, Willingham MC, Cheng SY, et al. Mice with a mutation in the thyroid hormone receptor beta gene spontaneously develop thyroid carcinoma: a mouse model of thyroid carcinogenesis. Thyroid. 2002; 12(11): 963-969, doi: 10.1089/105072502320908295, indexed in Pubmed: 12490073

21. Dentice $\mathrm{M}$, Luongo $\mathrm{C}$, Ambrosio $\mathrm{R}$, et al. $\beta$-Catenin regulates deiodinase levels and thyroid hormone signaling in colon cancer cells. Gastroenterology. 2012; 143(4): 1037-1047, doi: 10.1053/j.gastro.2012.06.042, indexed in Pubmed: 22771508.

22. Lee YS, Chin YT, Shih YJ, et al. Thyroid Hormone Promotes -Catenin Activation and Cell Proliferation in Colorectal Cancer. Horm Cancer. 2018; 9(3): 156-165, doi: 10.1007/s12672-018-0324-y, indexed in Pubmed: 29380230.

23. Rennert G, Rennert HS, Pinchev M, et al. A case-control study of levothyroxine and the risk of colorectal cancer. J Natl Cancer Inst. 2010; 102(8): 568-572, doi: 10.1093/jnci/djq042, indexed in Pubmed: 20305129.

24. Friedman GD, Schwalbe JS, Habel LA, et al. Re: a case-control study of levothyroxine and the risk of colorectal cancer. J Natl Cancer Inst. 2011; 103(21): 1637-1639, doi: 10.1093/jnci/djr374, indexed in Pubmed: 22010174

25. Boursi B, Haynes K, Mamtani R, et al. Thyroid dysfunction, thyroid hormone replacement and colorectal cancer risk. J Natl Cancer Inst. 2015; 107(6): djv084, doi: 10.1093/jnci/djv084, indexed in Pubmed: 25855726.

26. Mu G, Mu X, Xing H, et al. Subclinical hypothyroidism as an independent risk factor for colorectal neoplasm. Clin Res Hepatol Gastroenterol. 2015; 39(2): 261-266, doi: 10.1016/j.clinre.2014.08.002, indexed in Pubmed: 25242140

27. Chan YiX, Alfonso H, Chubb SA, et al. Higher thyrotropin concentration is associated with increased incidence of colorectal cancer in older men. Clin Endocrinol (Oxf). 2017; 86(2): 278-285, doi: 10.1111/cen.13271, indexed in Pubmed: 27809335

28. Chen YK, Lin CL, Cheng FTF, et al. Cancer risk in patients with Hashimoto's thyroiditis: a nationwide cohort study. Br J Cancer. 2013; 109(9): 2496-2501, doi: 10.1038/bjc.2013.597, indexed in Pubmed: 24084773.

29. Chen YK, Lin CL, Chang YJ, et al. Cancer risk in patients with Graves disease: a nationwide cohort study. Thyroid. 2013; 23(7): 879-884, doi: 10.1089/thy.2012.0568, indexed in Pubmed: 23421548.

30. Guillem-Llobat P, Dovizio M, Bruno A, et al. Aspirin prevents colorectal cancer metastasis in mice by splitting the crosstalk between platelets and tumor cells. Oncotarget. 2016; 7(22): 32462-32477, doi: 10.18632/oncotarget.8655, indexed in Pubmed: 27074574.

31. Chopra IJ, Chopra IJ. An assessment of daily production and significance of thyroidal secretion of 3, 3', 5'-triiodothyronine (reverse T3) in man. J Clin Invest. 1976; 58(1): 32-40, doi: 10.1172/JCI108456, indexed in Pubmed: 932209.

32. Dobrzycka M, Spychalski P, Łachiński AJ, et al. Statins and Colorectal Cancer - A Systematic Review. Exp Clin Endocrinol Diabetes. 2018 [Epub ahead of print], doi: 10.1055/a-0668-5692, indexed in Pubmed: 30149418

33. Pearce SHS, Brabant G, Duntas LH, et al. 2013 ETA Guideline: Management of Subclinical Hypothyroidism. Eur Thyroid J. 2013; 2(4): 215-228, doi: 10.1159/000356507, indexed in Pubmed: 24783053. 